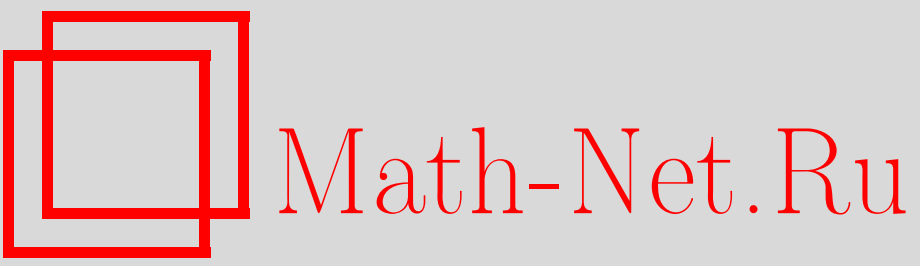

Информация от редакции, УМH, 2004, том 59, выпуск 2, 208

DOI: https://doi.org/10.4213/rm1719

Использование Общероссийского математического портала Math-Net.Ru подразумевает, что вы прочитали и согласны с пользовательским соглашением

http://www.mathnet.ru/rus/agreement

Параметры загрузки:

IP : 54.162 .127 .20

26 апреля 2023 г., 18:07:45 


\section{Информация от редакции}

По техническим причинам в статье В. В. Зудилина "Алгебраические соотношения для кратных дзета-значений”, опубликованной в томе 58 , вып. 1 (2003 г.), с. 3-32, содержится ряд однотипных опечаток (отсутствует верхний и нижний индексы "1"; в ряде мест символ "s" заменен на “1". Версия статьи на русском язьке, не содержащая опечаток, доступна в интернете по адресу http://math.ras.ru/UMN/; английский перевод статьи (Russian Mathematical Surveys. V. 58, № 1. Р. 1-29) опубликован без опечаток. Редакция приносит свои извинения. 